\title{
Effective Urban Energy Planning and Governance: A New Conceptual Framework
}

\author{
Yosef R. Jabareen ${ }^{1 *}$ \\ ${ }^{11}$ Technion - Israel Institute of Technology, Haifa, Israel \\ * Corresponding author. Tel: +922 52865336, Fax: +972 48294617, E-mail:jabareen@technion.ac.il
}

\begin{abstract}
Beyond any doubt climate change and its resulting uncertainties challenge the concepts, procedures, and scope of conventional approaches to the planning of our cities. Thus, demanding from us to situate the energy issue in the central when planning urban spaces. Yet, the literature is vague in the context of urban energy, and there is a lack of a theoretical framework that conceptualizes urban energy planning. Therefore, the aim of this paper is to propose a new multifaceted conceptual framework for theorizing urban energy planning based on multidisciplinary literature. Eventually, this study elaborates a conceptual framework that consists of eight concepts that were identified through a conceptual analysis of interdisciplinary literature on sustainability, climate change, ecology, economics, and urban planning. These concepts, which together constitute the theoretical framework of urban energy planning for climate change, are: Utopian Vision, Equity, Uncertainty, Natural Capital, Eco-Form, Integrative Approach, Ecological Energy, and Ecological Economics.
\end{abstract}

Keywords: Urban Planning, Energy, Theory, Conceptual Framework

\section{Introduction}

Climate change poses new risks and uncertainties that often lie outside our range of experience (IPCC, 2007: 719) and that have the potential to affect the social, economic, ecological, and physical systems of any given city. In this way, climate change and its resulting uncertainties challenge the concepts, procedures, and scope of conventional approaches to city planning, creating a need to rethink and revise current approaches. Decisively, it demands from us to situate the energy issue in the central when planning urban spaces. Yet, a striking weakness of the scholarship on the subject is its lack of multifaceted theorizing and the fact that it typically overlooks the multidisciplinary and complex nature of urban energy planning. Moreover, the literature is vague in the context of urban energy, and there is a lack of a theoretical framework that conceptualizes urban energy planning. Therefore, the aim of this paper is to propose a new multifaceted conceptual framework for theorizing urban energy planning based on multidisciplinary literature.

\section{Methodology}

A conceptual analysis method was used to build the conceptual framework (Jabareen 2009). This method is a grounded theory technique that aims "to generate, identify, and trace a phenomenon's major concepts, which together constitute its theoretical framework” (Jabareen 2009). Each concept possesses its own attributes, characteristics, assumptions, limitations, distinct perspectives, and specific function within the conceptual framework. The methodology delineates the following stages in conceptual framework building: a) mapping selected data sources; b) reviewing the literature and categorizing the selected data; c) identifying and naming the concepts; d) deconstructing and categorizing the concepts; e) integrating the concepts; f) synthesis, resynthesis, and making it all make sense; g) validating the conceptual framework; and h) rethinking the conceptual framework (Jabareen 2009). 


\section{Results}

\section{The Concepts of the Conceptual Framework}

The conceptual framework is composed of eight concepts (see Jabareen, 2006), as Fig1 shows. These concepts are:

a. Utopian Vision: This concept is concerned with a plan's future vision. Usually, urban planning seeks to bring about a different and more desirable future. Theoretically, the power of visionary or utopian thinking lies in its inherent ability to envision the future in terms of radically new forms and values (de Geus, 1999). An urban vision incorporating climate change as a central theme is of the utmost importance to practitioners, decision makers, and the public. Visionary frames are important in climate change, as they serve to identify problematic conditions and the need for change, to propose future alternatives, and to urge all stakeholders to act in concert to affect change. Climate change planning visions must provide people with an interpretive framework that enables them to understand how the issue is related to their own lives in the present and future, and to the world at large (Taylor, 2000; Benford and Snow, 2000: 614). This concept addresses the visionary and utopian aspects regarding future urban life, the city's potential role in climate change mitigation, and the city vision regarding energy production and consumption as well.

b. Equity: Equity is a key concept in evaluating climate change policies (IPCC, 2001). The impacts of climate change and climate change mitigation policies are "socially differentiated," and are therefore matters of local and international distributional equity and justice (Adger, 2001: 929; O'Brien et. al., 2004; Paavola et al., 2006). Some argue that inequality leads to greater environmental degradation and that a more equitable distribution of power and resources would result in improved environmental quality (Boyce et al. 1999; Agyeman et al., 2002; Solow 1991, Stymne and Jackson, 2000). Moreover, there are individuals and groups within all societies who are more vulnerable than others and lack the capacity to adapt to climate change (IPCC, 2007: 719). A society's vulnerability is influenced by its development path, physical exposure, resource distribution, social networks, government institutions, and technological development (, 2007: 719-720). The concept of equity addresses social aspects, including: environmental justice; public participation; and methods of addressing each community’s vulnerability to climate change (urban vulnerability matrix).

c. Uncertainty Management: Uncertainty "is a perceived lack of knowledge, by an individual or group, which is relevant to the purpose or action being undertaken and its outcomes" (Abbot, 2009: 503). The new urban uncertainties posed by climate change challenge the concepts, procedures, and scope of planning. In order to cope with the new challenges, planners must develop a greater awareness and place mitigation and policies for "adaptation," or actual adjustments that might eventually enhance resilience and reduce vulnerability to expected climate changes, at the center of the planning process (Adger et. Al., 2007: 720). Planners must also develop a better understanding of the risks climate change poses for infrastructure, households, and communities. To address these risks, planners have two types of uncertainty or adaptation management at their disposal: 1) Ex-ante management, or actions taken to reduce and/or prevent risky events; and 2) Ex-post management, or actions taken to recover losses after a risky event (Heltberg et al., 2009).

d. Natural Capital: Natural capital refers to "the stock of all environmental and natural resource assets, from oil in the ground to the quality of soil and groundwater, from the stock of fish in the ocean to the capacity of the globe to recycle and absorb carbon" (Pearce et. al., 1990: 1). Maintaining constant natural capital is an important criterion for sustainability 
(Pearce and Turner, 1990: 44; Geldrop and Withagen, 2000). The stock of natural capital should not decrease, as this could endanger the ecological system and threaten the ability of future generations to generate wealth and maintain their well-being. This concept addresses the consumption and - equally as important - the renewal of natural assets that are used for development, such as land, water, air, and open spaces.

e. Integrative Approach: Planning for climate change is more complex than the conventional approach to planning as it is undertaken in a context of great uncertainty. This context poses new challenges for collaboration among public, private, and civil institutions and organizations on all levels. Integrating the many different stakeholders and agents into planning is essential for achieving climate change objectives. The "ability of a governance system to adapt to uncertain and unpredicted conditions is a new notion” (Mirfenderesk and Corkill, 2009: 152). Therefore, adaptive management requires new planning strategies and procedures that transcend conventional planning approaches by integrating uncertainties into the planning process and prioritizing stakeholders' expectations in an uncertain environment. Plans should also be "flexible enough to quickly adapt to our rapidly changing environment" (Mirfenderesk and Corkill, 2009).

f. Ecological Energy: The clean, renewable, and efficient use of energy is a central theme in planning for the achievement of climate change objectives. This concept evaluates how a plan addresses the energy sector and whether it proposes strategies to reduce energy consumption and to use new, alternative, and clean energy sources.

g. Ecological Economics: This concept is based on the assumption that environmentally sound economics can play a decisive role in achieving climate change objectives in a capitalist world. Cities that are committed to climate change mitigation and sustainability should stimulate markets for 'green' products and services, promote environmentally friendly consumption, and contribute to urban economic development by creating a cleaner environment (Hsu, 2006: 11; Mercer Human Resources Consulting, 2005). In this spirit, the American Recovery and Reinvestment Plan, proposed by President Barack Obama, calls for spurring "job creation while making long-term investments in energy, and infrastructure," and increasing "production of alternative energy" (White House, 2009).

h. Eco-Form: The physical form of a city affects its habitats and ecosystems, the everyday activities and spatial practices of its inhabitants, and, eventually, climate change. This concept evaluates spatial planning, architecture, design, and the ecologically-desired form of the city and its components (such as buildings and neighborhoods). Jabareen (2006) suggests the following set of nine planning typologies, or criteria of evaluation, which are helpful in evaluating plans from the perspective of eco-form as follows:

Compactness refers to urban contiguity and connectivity and suggests that future urban development should take place adjacent to existing urban structures (Wheeler, 2002). Compact urban space can minimize the need to transport energy, materials, products, and people (Elkin et. al., 1991). Intensification, a major strategy for achieving compactness, uses urban land more efficiently by increasing the density of development and activity, and involves: developing previously undeveloped urban land; redeveloping existing buildings or previously developed sites; subdivisions and conversions; and additions and extensions (Jenks, 2000: 243). 
Sustainable Transport suggests that planning should promote sustainable modes of transportation through traffic reduction; trip reduction; the encouragement of non-motorized travel (such as walking and cycling); transit-oriented development; safety; equitable access for all; and renewable energy sources, (Cervero, 2003; Clercq and Bertolini, 2003).

Density is the ratio of people or dwelling units to land area. Density affects climate change through differences in the consumption of energy, materials, and land for housing, transportation, and urban infrastructure. High density planning can save significant amounts of energy (Carl, 2000; Walker and Rees, 1997; Newman and Kenworthy, 1989).

Mixed Land Uses indicates the diversity of functional land uses, such as residential, commercial, industrial, institutional, and transportation. It allows planners to locate compatible land uses in close proximity to one another in order to decrease the travel distance to between activities. This encourages walking and cycling and reduces the need for car travel, as jobs, shops, and leisure facilities are located in close proximity of one another (Parker, 1994; Alberti, 2000; Van and Senior, 2000; Thorne and Filmer-Sankey, 2003).

Diversity is "a multidimensional phenomenon" that promotes other desirable urban features, including a larger variety of housing types, building densities, household sizes, ages, cultures, and incomes (Turner and Murray, 2001: 320). Diversity is vital for cities. Without it, the urban system declines as a living place (Jacobs 1961) and the resulting homogeneity of built forms, which often produces unattractive monotonous urban landscapes, leads to increased segregation, car travel, congestion, and air pollution (Wheeler, 2002).

Passive Solar Design aims to reduce energy demands and to provide the best use of passive energy through specific planning and design measures, such as orientation, layout, landscaping, building design, urban materials, surface finish, vegetation, and bodies of water. This facilitates optimum use of solar gain and microclimatic conditions and reduces the need for the heating and cooling of buildings by means of conventional energy sources (Owens, 1992; Thomas, 2003; Yannis, 1998: 43).

Greening, or bringing "nature into the city," makes positive contributions to many aspects of the urban environment, including: biodiversity; the lived-in urban environment; urban climate; economic attractiveness; community pride; and health and education (Beatley 2000; Swanwick et al., 2003; Forman, 2002; Dumreicher et al., 2000; Beer et. al.,, 2003; Ulrich, 1999).

Renewal and Utilization refers to the process of reclaiming the many sites that are no longer appropriate for their original intended use and can be reclaimed for a new purpose, such as brownfields. Cleaning, rezoning, and developing contaminated sites are key aspects of revitalizing cities and neighbourhoods and contribute to their sustainability and to a healthier urban environment.

Planning Scale influences and is influenced by climate change. For this reason, desirable planning scale should be considered and integrated in plans for regional, municipal, district, neighbourhood, street, site, and building levels. Planning that moves from macro to micro levels has a more holistic and positive impact on climate change. 


\section{Discussion and/or Conclusions}

The conceptual framework is not a mere collection of concepts. Rather, all concepts are interrelated and interwoven with one another; each plays an important role in the framework as a whole. The conceptual framework consists of eight concepts of assessment that were identified through conceptual analyses of interdisciplinary literature on sustainability and climate change. Together, these concepts - each of which represents a distinctive aspect of urban energy planning - form the conceptual framework. Importantly, each concept contributes to the planning of urban energy in its domain. The positive contribution o all concepts together will lead to effective urban energy governance. The overlooking of one concept or more will cause various negative externalities to climate change.



Fig. 1 Conceptual framework for urban energy.

\section{References}

[1] IPCC - S.H. Schneider, S. Semenov, A. Patwardhan, I. Burton, C.H.D. Magadza, M. Oppenheimer, A.B. Pittock, A. Rahman, J.B. Smith, A. Suarez and F. Yamin, Assessing key vulnerabilities and the risk from climate change. Climate Change 2007: Impacts, 
Adaptation and Vulnerability. Contribution of Working Group II to the Fourth Assessment Report of the Intergovernmental Panel on Climate Change, M.L. Parry, O.F. Canziani, J.P. Palutikof, P.J. van der Linden and C.E. Hanson, Eds., Cambridge University Press, Cambridge, UK, 2007, pp. 779-810.

[2] Y. Jabareen, Building Conceptual Framework: Philosophy, Definitions and Procedure, International Journal of Qualitative Methods, Vol 8(4), 2009, pp. 49-62.

[3] Y. Jabareen, Sustainable Urban Forms: Their Typologies, Models, and Concepts, Journal of Planning Education and Research, Vol. 26 (1), 2006, pp. 38-52.

[4] M. de. Geus, Ecological Utopias: Envisioning the Sustainable Society. Utrecht: International Books, 1999.

[5] D. E. Taylor, The Rise of the Environmental Justice Paradigm: Injustice Framing and the Social Construction of Environmental Discourses American Behavioral Scientist 43, 2000, pp. 508-580.

[6] Benford Robert D. and Snow David A. 2000. Framing Processes and Social Movements: An Overview and Assessment. Annual Review of Sociology, Vol. 26: 611-639

[7] IPCC.Third Assessment Report: Climate Change 2001 (TAR).

[8] W.N Adger,. S. Agrawala, M.M.Q. Mirza, C. Conde, K. O’Brien, J. Pulhin, R. Pulwarty, B. Smit and K. Takahashi, Assessment of adaptation practices, options, constraints and capacity. Climate Change 2007: Impacts, Adaptation and Vulnerability. Contribution of Working Group II to the Fourth Assessment Report of the Intergovernmental Panel on Climate Change, M.L. Parry, O.F. Canziani, J.P. Palutikof, P.J. van der Linden and C.E. Hanson, Eds., Cambridge University Press, Cambridge, UK, 2007, pp. 717-743.

[9] R. O'Brien, Leichenko, U. Kelkar, H. Venema, G. Aandahl, H. Tompkins, A. Javed, S. Bhadwal, A. Barg, L.P. Nygaard and J. West, Mapping vulnerability to multiple stressors: climate change and globalization in India, Global Environmental Change 14, 2004, pp. 303-313.

[10]J. Paavola, and Adger W. Neil, Fair adaptation to climate change. Ecological Economics. Volume 56, Issue 4, 2006, pp. 594-609.

[11]J.K. Boyce, Klemer, A.R., Templet, P.H. and Willis, C.E, Power distribution, the environment, and public health: a state-level analysis. Ecological Economics. 29, 1, 1999, pp. 127-140.

[12] J. Agyeman, Bullard, R. D., \& Evans, B. Exploring the nexus: Bringing together sustainability, environmental justice and equity. Space \& Polity, Vol 6(1), 2002, pp. 7790 .

[13]R. Solow, Sustainability: An Economist's Perspective. The Eighteenth J. Seward Johnson Lecture. Woods Hole, MA: Woods Hole Oceanographic Institution, 1999.

[14] J. Abbott. Planning for complex metropolitan regions: A better future or a more certain one? Journal of Planning Education and Research, vol.28, 2009, 503-517.

[15]W.N. Adger, Scales of governance and environmental justice for adaptation and mitigation of climate change. Journal of International Development, Vol. 13(7), 2001, pp. 921-931.

[16]R. Heltberg, Paul Bennett Siegel, Steen Lau Jorgensen. 2009. Addressing human vulnerability to climate change: Toward a 'no-regrets' approach. Global Environmental Change, 19, 2009, pp. 89-99. 
[17]D. Pearce, Edward, Barbier., and Anil Markandya. Sustainable development: Economics and environment in the Third World. London: Earthscan Publications, 1990.

[18] Geldrop, J. and C. Withagen, Natural capital and sustainability. Ecological Economics, Vol. 32 (3), 2000, pp. 445-455.

[19]H. Mirfenderesk and Corkill David, Sustainable management of risks associated with climate change. International Journal of Climate Change Strategies and Management, Vol. 1(2), 2009, pp.146-159.

[20]D. Hsu David, Sustainable New York City. New York City: Design Trust for Public Space and the New York City Office of Environmental Coordination, 2006.

[21] Mercer Human Resources Consulting, Quality of Living Survey: New York City. Private communication, 2004.

[22] White House http://www.whitehouse.gov/issues/Economy; see also http://www.recovery.gov/Pages/home.aspx, 2009.

[23]S. Wheeler, Stephen. M. Constructing sustainable development/safeguarding our common future: Rethinnking sustainable development. Journal of the American Planning Association 68:1, 2002, pp. 110-111.

[24]T. Elkin, McLaren, Duncan, and Hillman, Mayer, Reviving the city: Towards sustainable urban development, Friends of the Earth, London, 1991.

[25] M. Jenks, The acceptability of urban intensification. In Achieving sustainable urban form, edited by Williams K., Burton E., and Jenks M., London: E \& FN SPON, 2000.

[26]S. Owens, Energy, environmental sustainability and land-use planning. In Sustainable development and urban form, edited by Michael, Breheny. London: Pion, 1992, pp. 79105,

[27]R. Cervero, RobertCoping with Complexity in America's Urban Transport Sector. The 2nd International Conference on the Future of Urban Transport, Göteborg, Sweden, 2003.

[28]F. Clercq, and L. Bertolini, Achieving sustainable accessibility: An evaluation of policy measures in the Amsterdam area. Built Environment 29:1, 2003, pp. 36-47.

[29]P. Carl, Urban density and block metabolism. In Architecture, city, environment. Proceedings of PLEA 2000, edited by Steemers Koen and Simos Yannas, London: James \& James, 2000, pp. 343-347.

[30]L. Walker, and Rees William. Urban density and ecological footprints - An analysis of Canadian households. In Eco-city dimensions: Healthy communities, healthy planet, edited by Roseland Mark, New Society Publishers, 1997.

[31]P. Newman, and Kenworthy, J. Gasoline consumption and cities: a comparison of US cities with a global survey. Journal of the American Planning Association 55, 1989, pp. 23-37.

[32] T. Parker, The land use-air quality linkage: How land use and transportation affect air quality. Sacramento: California Air Resources Board. 1994.

[33]Alberti, M. (2000) Urban form and ecosystem dynamics: Empirical evidence and practical implications. In Achieving sustainable urban form, edited by Williams K., Burton E., and Jenks M., London: E \& FN Spon. 2000, pp. 84-96. 
[34] Van Uyen-Phan and Martyn Senior. The contribution of mixed land uses to sustainable travel in cities. In Achieving sustainable urban form, edited by Williams K., Burton E., and Jenks M., London: E \& FN Spon, 2000, pp. 139-148.

[35]R. Thorne, and William, Filmer-Sankey, Transportation. In Sustainable urban design, edited by Thomas Randall, 25-32, London: Spon Press, 2003.

[36]S. R. Turner S. and Margaret. S. Murray, Managing growth in a climate of urban diversity: South Florida's Eastward ho! Initiative. Journal of Planning Education and Research 20, 2001, 308-328

[37] J. Jacobs, Jane, The death and life of great American cities, New York: Random House, 1961.

[38]R. Thomas, Building design. Sustainable urban design: An environmental approach, edited by In Thomas R. and Fordham M., 46-88, London: Spon Press, 2003.

[39]S. Yanns, Living with the city: Urban design and environmental sustainability. In Environmantly friendly cities, edited by Maldonado Eduardo and Simon Yannas, 41-48, London: James \& James, 1998.

[40]T. Beatley, Green urbanism: Learning from European cities. Washington, D.C.: Island Press, 2000.

[41]C. Swanwick, , Nigel Dunnett., and Helen Woolley, Nature, role and value of green space in towns and cities: An overview, Built Environment 29:2, 2003, pp. 94-106.

[42]R. T. Forman, Richard, The missing catalyst: Design and planning with ecology. In Ecology and design: Frameworks for learning, edited by Johnson Bart T. and Hill Kristina, Washington, DC: Island Press, 2000.

[43]H. Dumreicher, Heidi, L. Richard S., and Yanarella, Ernest J, The appropriate scale for "low energy": Theory and practice at the Westbahnhof. In Architecture, city, environment. Proceedings of PLEA 2000, edited by Steemers Koen and Simos Yannas, London: James \& James. 2000, pp. 359-363.

[44]A. Beer, T. Delshammar, and P. Schildwacht, A changing understanding of the role of greenspace in high-density housing: A European perspective. Built Environment, 29:2, 2003, pp. 132-143.

[45]R. S. Ulrich, Roger, Effects of gardens on health outcomes: theory and research, in Healing gardens: Therapeutic benefits and design recommendations, edited by Marcus, Clare Cooper. and Marni Barnes., New York: Whiley, 1999. 